\title{
PENGARUH GEL EKSTRAK KULIT KENTANG(SOLANUM TUBEROSUM L.) TERHADAP LUAS LUKA BAKAR DERAJAT II A
}

\author{
Diandra Reski Maharani ${ }^{1}$, Ruby Riana Asparini ${ }^{2}$, Bambang Mulyawan $^{3}$ \\ Fakultas Kedokteran, Universitas Muhammadiyah Malang \\ J1. Bendungan Sutami 188 A Malang, 65145 \\ Email : diandrarezkym@yahoo.com
}

\begin{abstract}
ABSTRAK
Luka bakar derajat II A adalah luka yang disebabkan oleh kontak langsung atau tidak langsung dengan suhu tinggi seperti api, air panas, listrik, bahan kimia dan radiasi. Pengobatan baku emas memiliki harga yang cukup relatif mahal dan ketersediaan yang kurang. Sedangkan kulit kentang memiliki kandungan glycoalkaloid dan flavonoid sebagai antioksidan sehingga pemberian gel ekstrak kulit kentang diharapkan dapat mengurangi luas luka bakar derajat II A Untuk mengetahui pengaruh gel ekstrak kulit kentang pada luas luka bakar derajat II A True Experimental, Post Test Only Control Group Design. Gel Ekstrak kulit kentang konsentrasi 5\%,10\% dan 15\% diberikan selama 15 hari secara topikal diukur pada hari ke-3 dan ke-10. Analisis data menggunakan One Way ANOVA, Tukey, korelasi pearson, dan regresi linear Gel ekstrak kulit kentang dapat menurunkan luas luka bakar secara bermakna dengan signifikansi 0.00 (ANOVA p=0,05) pada hari ke 3 dan ke 10. Konsentrasi optimal adalah 15\%. Nilai korelasi penelitian ini pada hari ke-3 adalah -899 yang menunjukkan hubungan signifikan sangat kuat, uji regresi menunjukkan pengaruh $80 \%$ dan nilai korelasi penelitian ini pada hari ke-10 adalah -921 yang menunjukkan hubungan sangat kuat, uji regresi menunjukkan pengaruh 85\%. Gel Ekstrak Kulit Kentang (Solanum Tuberosum L.) dapat menurunkan luas luka bakar derajat II A tikus putih jantan (Rattus novergicus Strain wistar).
\end{abstract}

Kata kunci : Luka bakar derajat II A, Gel Ekstrak kulit kentang

\begin{abstract}
ABTRACT
A Second degree burns are injuries caused by direct or indirect contact with a bigh temperature such as fire, hot water, electricity, chemicals and radiation. Treatment of the gold standard has a price they are relatively expensive and less availability. While the potato skin contains flavonoids as antioxidants glycoalkaloid and thereby granting the potato peel extract gel is expected to reduce the extent of second degree of burns.To determine the effect on the potato peel extract gel broad of second degree of burnsTrue Experimental, Post Test Only Control Group Design. potato peel extract gel concentration of 5\%,10\% and 15\% is given for 15 days topically measured on day 3 and 10. Analysis of the data using One Way ANOVA, Tukey, Pearson correlation and linear regression. Gel potato peel extract can reduce significantly the burn area with a significance $0.00($ ANOVA $p=0.05)$ on days 3 and 10. The optimal concentration is 15\%. The correlation value of this study on day 3 is -899 which showed a significant correlation was very strong, regression test shows the effect of $80 \%$ and this research correlation value on day 10 is -921 which showed a very strong correlation, regression test shows the effect of $85 \%$. Potato peel extract gel (Solanum Tuberosum L.) extent of second degrees burn white male rats (Rattus novergicus Wistar strain).
\end{abstract}

Keywords: Second degree burn, Potato peel 


\section{PENDAHULUAN}

Luka bakar derajat II A adalah luka yang disebabkan oleh kontak langsung atau tidak langsung dengan suhu tinggi seperti api, air panas, listrik, bahan kimia dan radiasi (Nugroho,2012).Luka bakar karena api atau akibat tidak langsung dari api,misalnya tersiram air panas,banyak terjadi pada kecelakaan rumah tangga(Depkes $R I, 2007)$. Beberapa obat gold standard untuk penatalaksanaan dari luka bakar tersebut diantaranya hydrogel efektif digunakan untuk luka bakar derajat II A. Tetapi pengobatan gold standar memiliki harga yang cukup relatif mahal dan ketersediaan yang kurang ( $M N$ Syuhar,2012).Menurut penelitian VS Patange 1996, tentang Dressing wounds with potato peel bahwa kulit kentang dapat memfasilitasi proses penyembuhan luka dengan memelihara kelembapan. Kulit kentang mudah diterapkan dan juga biaya yang efektif dan terjangkau.

\section{BAHAN DAN METODE PENELITIAN}

Penelitian experimental dengan pendekatan True Experimental. Penelitian dilakukan selama 15 hari di Laboratorium Biomedik Fakultas Kedokteran Universitas Muhammadiyah Malang dengan populasi yang digunakan adalah tikus putih strain wistar (Rattus norvegicus) jantan sebanyak 24 ekor yang dibagi kedalam 4 kelompok meliputi : kelompok kontrol I, kelompok perlakuan II, kelompok perlakuan III, kelompok perlakuan IV,masingmasing kelompok terdapat 6 ekor tikus putih jantan. Semua sampel penelitian diadaptasikan selama 1 minggu pada kandang tikus yang berukuran $43 \mathrm{~cm} \times 37 \mathrm{~cm} \times 15 \mathrm{~cm}$ dan telah diberi sekam.

Pada kelompok kontrol I, diberi gel plain sebagai placebo kemudian diamati dan diukur luas lukanya pada hari ke -3 dan 10.Untuk kelompok perlakuan, diberi gel ekstrak kult kentang 5\%pada permukaan lukanya.Pada kelompok perlakuan I diamati dan diukur pada hari ke-3 dan 10.Pada kelompok perlakuan II diberi gel ekstrak 10\% diamati dan diukur pada hari ke-3 dan 10 dan pada kelompok perlakuan III diberi gel 15\% diamati dan diukur pada hari ke -3 dan 10

Pemberian gel plain dan gel ekstrak kulit kentang dengan konsentrasi 5\%,10\% dan 15\% hanya dilakukan pada awal percobaan yang kemudian akan ditutup dengantransparent dressing (Nexcare
3M) sampai hari pengamatan ataupengukuran sesuai dengan masing-masing kelompok.

Perlakuan luka pada tikus sendiri dilakukan pada punggung tikus dengan menggunakan logam kuning berdiameter $2 \mathrm{~cm}$ yang telah dipanaskan di dalam air mendidih $100^{\circ} \mathrm{C}$ selama 3 menit dan ditempelkan pada punggung tikus selama 10 detik tanpa disertai dengan penekanan pada saat menempelkan (Erlia Eva,2014).Sebelum dilakukan perlukaan pada punggung tikus, tikus terlebih dahulu dianastesi untuk mengurangi rasas sakit pada tikus, menggunakan ketamine secara intramuscular dengan dosis $60 \mathrm{mg} / \mathrm{kg}$ (Fatemi et al,2014)setelah itu dilakukan pengukuran bulu pada punggung tikus selebar luka yang akan dibuat pada punggung tersebut.

Pembuatan sediaan gel ekstrak kulit kentang untuk intervesi luka dengan cara menimbang kulit kentang dengan konsentrasi 5\%,10\%,dan 15\% dan setelah itu dilarutkan ke dalam gel dan ditaruh dalam wadah disimpan di dalam kulkas.Setelah percobaan, setiap kelompok tikus dianastesi letal di dalam kotak yang berisi kloroform per-inhalasi setelah itu dimasukkan kedalam polybag dan dikuburkan

Analisa data yang digunakan pada penelitian ini adalah One Way ANOVA yang merupakan uji hipotesis komparatif variable numerik dengan distribusi normal dan varian data homogen, serta tidak berpasangan lebih dari dua kelompok. Uji ini digunakan untuk membandingkan antara kelompok kontrol dan kelompok perlakuan.Kemudian dilanjutkan dengan uji korelasi Pearson untuk mengetahui hubungan antara kedua variabel yang diuji.Kemudian dilanjutkan dengan uji regresi. Uji analisa tersebut menggunakan program SPSS 19.0.

\section{HASIL PENELITIAN}

Penelitian ini menggunakan 30 tikus putih jantan yang sehat (gerakan aktif dan mata yang jernih) dengan rentang umur 2-3 bulan dan berat 150-200 gram. 
Tabel 5.1 Data Luas Luka Bakar pada Tikus Putih

\begin{tabular}{|c|c|c|c|c|c|c|c|}
\hline \multirow{2}{*}{ Kelompok } & \multicolumn{5}{|c|}{ Ulangan } & \multirow{2}{*}{ Rata- rata } & $\begin{array}{c}\text { Standart } \\
\text { Deviasi }\end{array}$ \\
\cline { 2 - 7 } & 1 & 2 & 3 & 4 & 5 & & 0.358 \\
\hline I & & 2.06 & 2.7 & 2 & 1.86 & 2.224 & 0.108 \\
\hline II & 2 & 1.9 & 2.03 & 2.2 & 2.03 & 2.032 & 0.117 \\
\hline III & 1.4 & 1.3 & 1.6 & 1.33 & 1.4 & 1.406 & 0.138 \\
\hline IV & 1.43 & 1.56 & 1.53 & 1.8 & 1.63 & 1.59 & 0.162 \\
\hline V & 1.4 & 1.1 & 1.1 & 1.36 & 1.06 & 1.204 & 0.412 \\
\hline VI & 0.8 & 0.31 & 0.63 & 1.03 & 0.96 & 0.684 & \\
\hline
\end{tabular}

Sumber : Data primer yang diolah (2016)

Hasil dari penelitian tersebut menunjukkan bahwa semua kelompok kontrol masing - masing kelompok memiliki luas lebih lebar daripada kelompok perlakuan yang telah diberi gel ekstrak kulit kentang.Hasil dari penelitian tersebut menunjukkan bahwa semua kelompok kontrol masing - masing kelompok memiliki luas lebih lebar daripada kelompok perlakuan yang telah diberi gel ekstrak kulit kentang.Hasil uji normalitas data menggunakan sapiro wilk didapatkan masing - masing kelompok yaitu kelompok gel 5\%,10\%, dan 15\% baik kelompok kontrol maupun perlakuan, memiliki nilai signifikansi lebih dari 0,05 yang menyatakan bahwa sebaran data normal.

Hasil uji homogenitas data yang menggunakan Levene menunjukkan nilai signifikansi lebih dari 0,05 yang berarti sebaran data homogen. Hasil uji komparasi menggunakan uji One Way Anova pada kelompok gel estrak 5\%,10\% dan 15\% didapatkan nilai signifikansi kurang dari 0,05 yang berarti terdapat pengaruh yang bermakna antara pemberian gel ekstrak kulit kentang dengan luas luka bakar tersebut.

Uji korelasi pearson dilakukan sebanyak 2, yang pertama yaitu korelasi antar kelompok kontrol dan perlakuan pada hari ke-3 dan didapatkan nilai $\mathrm{p}<0,05$ dan nilai $\mathrm{r}$ sebesar -0808, yang bermakna terdapat korelasi yang signifikan antara lama hari dengan luas luka pada kelompok kontrol dengan keeratan hubungan yang tergolong sangat kuat. Uji korelasi antar kelompok perlakuan hari ke-10 menunjukkan nilai $\mathrm{p}<0,05$ dan nilai $\mathrm{r}$ sebesar 0,849 yang bermakna terdapat korelasi yang signifikan antara lama hari dengan luas luka pada kelompok perlakuan dengan keeratan hubungan yang tergolong sangatkuat.Besar pengaruh pemberian gel ekstrak kulit kentang terhadap luas luka bakar dapat dianalisis menggunakan uji regresi linier dengan hasil yang didapatkan $\mathrm{Y}=1.423-$ $0.89 \mathrm{X}$ (Gel ekstrak hari ke-3 dan hydrogel). dimana $\mathrm{Y}$ adalah rata-rata luas permukaan luka bakar, sedangkan X adalah pemberian gel ekstrak kulit kentang (Solanum Tuberosum L.).

Hal ini dapat diartikan bahwa tanpa mempertimbangkan pengaruh dari pemberian gel ekstrak kulit kentang (Solanum Tuberosum L.), maka rata-rata luas permukaan luka bakar derajat II (A) pada tikus putih strain wistar (Rattus norvegicus) akan cenderung tetap tinggi secara konstan $1.423 \mathrm{~cm}$ (karena koefisien konstanta bernilai positif). Namun apabila mempertimbangkan pengaruh dari pemberian gel ekstrak kulit kentang (Solanum Tuberosum L.), maka hal ini justru akan menurunkanluas permukaan luka bakar derajat II (A) pada tikus putih strain wistar (Rattus norvegicus) hingga $0.89 \mathrm{~cm}$.

Uji regresi linier dengan hasil yang didapatkan $\mathrm{Y}=0.990-0.60 \mathrm{X}$ (Gel ekstrak hari ke-10 dan hydrogel). dimana $\mathrm{Y}$ adalah rata-rata luas permukaan luka bakar, sedangkan $\mathrm{X}$ adalah pemberian gel ekstrak kulit kentang (Solanum Tuberosum L.). Hal ini dapat diartikan bahwa tanpa mempertimbangkan pengaruh dari pemberian gel ekstrak kulit kentang (Solanum Tuberosum L.), maka rata-rata luas permukaan luka bakar derajat II (A) pada tikus putih strain wistar (Rattus norvegicus) akan cenderung 
tetap tinggi secara konstan $0.990 \mathrm{~cm}$ (karena koefisien konstanta bernilai positif).

Namun apabila mempertimbangkan pengaruh dari pemberian gel ekstrak kulit kentang (Solanum Tuberosum L.), maka hal ini justru akan menurunkanluas permukaan luka bakar derajat II (A) pada tikus putih strain wistar (Rattus norvegicus) hingga $0.60 \mathrm{~cm}$. Selanjutnya, berdasarkan hasil uji regresi hari ke-3 juga menunjukkan nilai koefisien determinasi $\left(\mathrm{R}\right.$ Square $=\mathrm{r}^{2}$ ) yang menyatakan besarnya pengaruh dari pemberian gel ekstrak kulit kentang (Solanum Tuberosum L.) terhadap luas permukaan luka bakar derajat II (A) pada tikus putih strain wistar (Rattus norvegicus), dalam bentuk persentase, dan persentase sisanya (1-R Square) ditentukan oleh faktor lain. Jadi dapat dikatakan bahwa pemberian Gel ekstrak kulit kentang(Solanum Tubersoum L.)berpengaruh terhadap luas permukaan luka bakar derajat II (A) pada tikus putih strain wistar (Rattus norvegicus) hingga 80,8\% . Sedangkan 19.2\% keragaman luas permukaan luka bakar derajat II (A) pada tikus putih strain wistar (Rattus norvegicus) tersebut dipengaruhi oleh faktor lain selain dari pemberian gel ekstrak kulit kentang (Solanum Tuberosum L.).

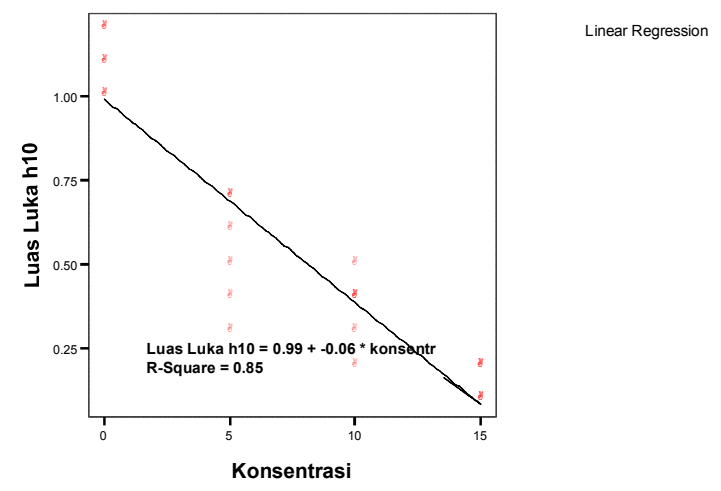

Gambar 5.1 Hasil uji regresi linier hari ke-3

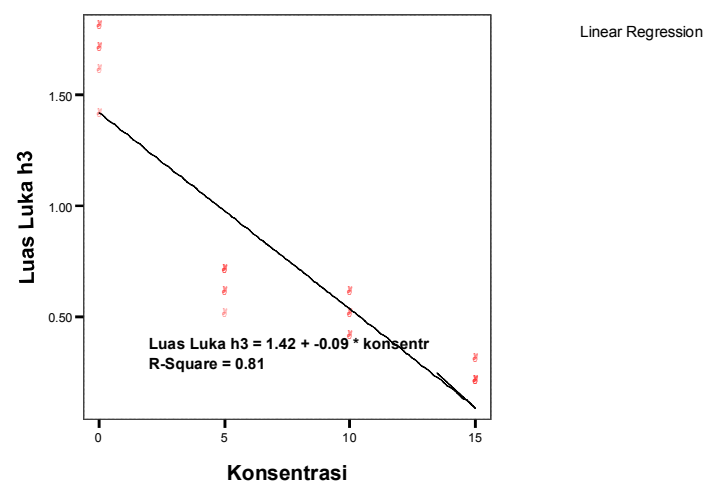

Gambar 5.2 Hasil uji regresi linier hari ke-10

Hasil uji regresi hari ke-10juga menunjukkan nilai koefisien determinasi $\left(\mathrm{R}\right.$ Square $=\mathrm{r}^{2}$ ) yang menyatakan besarnya pengaruh dari pemberian gel ekstrak kulit kentang (Solanum Tuberosum L.) terhadap luas permukaan luka bakar derajat II (A) pada tikus putih strain wistar (Rattus norvegicus), dalam bentuk persentase, dan persentase sisanya (1-R Square) ditentukan oleh faktor lain. Jadi dapat dikatakan bahwa pemberian Gel ekstrak kulit kentang(Solanum Tubersoum L.)berpengaruh terhadap luas permukaan luka bakar derajat II (A) pada tikus putih strain wistar (Rattus norvegicus) hingga 84.9\% . Sedangkan $15.1 \%$ keragaman luas permukaan luka bakar derajat II (A) pada tikus putih strain wistar (Rattus norvegicus) tersebut dipengaruhi oleh faktor lain selain dari pemberian gel ekstrak kulit kentang (Solanum Tuberosum L.).

\section{PEMBAHASAN}

Penelitian ini telah membuktikan bahwa terjadi perbedaan rata-rata luas luka bakar derajat II A antara tikus yang diberikan gel ekstrak kulit kentang dengan yang tidak diberikan gel ekstrak kulit kentang.Penelitian ini terdiri dari 4 kelompok dengan 3 macam konsentrasi yang berbeda. Pada penelitian ini menunjukkan hasil terdapat perbedaan yang signifikan antara pemberian gel ekstrak kulit kentang dengan konsentrasi $5 \%, 10 \%$ dan $15 \%$ pada hari ke-3 dan ke-10 terhadap luas luka bakar derajat II 
A pada kelompok kontrol positif yang dapat dilihat hasil statistika pos hoc tukey.

Penelitian ini telah membuktikan bahwa terjadi perbedaan rata-rata luas luka bakar derajat II A antara tikus yang diberikan gel ekstrak kulit kentang dengan yang tidak diberikan gel ekstrak kulit kentang. Perlakuan dengan memberikan logam panas berbentuk lingkaran dengan suhu $100^{\circ} \mathrm{C}$ bisa membentuk luka bakar derajat II A, dimana luka bakar derajat II A terjadi kerusakan pada sebagian dermis, folikel rambut dan kelenjar keringat utuh (Grunwald TB,2008)

Pada penelitian ini pemberian gel ekstrak kulit kentang dapat menurunkan luas luka bakar dengan presentase hari ke-3 sebesar 80\% dan hari ke-10 sebesar $85 \%$, dimana sisanya pada hari ke3 sebesar $20 \%$ dan hari ke-10 sebesar 15\% dipengaruhi oleh adanya faktor endogen maupun eksogen. Faktor endogen antara lain berupa adanya anti oksidan alami tubuh yang dapat membantu penyembuhan luka secara alami sementara faktor eksogen berupa proses adaptasi dari masing-masing tikus yang berbeda sehingga mempengaruhi penyembuhan luka, faktor lingkungan dan aktivitas tikus putih itu sendiri.

Gel ekstrak kulit kentang (Solanum Tuberosum L.) bila diterapkan pada luka dapat mempercepat penyembuhan melalui berbagai modalitas glycoalkaloid seperti alpha chaconine dan alpha solanin. Alpha solanin berguna untuk mematikan mikroorganisme, glycoalkaloid memiliki sifat yaitu sebagai anti piretik, anti inflamasi, dan antibiotik terhadap bakteri patogen, protozoa dan jamur sehingga bisa digunakan untuk luka yang bernanah. Lingkungan yang asam dapat merusak pertumbuhan bakteri yang diperoleh dari kentang. Flavonoid akan menghilangkan paparan radikal bebas yang ada di luka. Komponen glycoalkaloid akan mengurangi peradangan. Sesuai dengan hasil penelitian sebelumnya tentang menajemen penyembuhan luka nekrosis dengan dressing kulit kentang yang dapat mempercepat penyembuhan dengan pembentukan jaringan granulasi baru sehingga menurunkan luas luka (Manjunath K.S 2013), sehingga dengan pemberian gel ekstrak kulit kentang dapat membantu penurunan luas luka pada tikus putih jantan dengan luka bakar derajat II (A).

Penelitian ini memiliki keterbatasan yaitu aktivitas tikus yang sangat meningkat pada malam hari dapat menyebabkan dressing pada punggung tikus terlepas dengan sendirinya, hal ini terjadi pada beberapa tikus, sehingga kelembaban tidak terjaga dengan baik serta luka dapat berkontak langsung dengan sekam yang tercampur dengan urin dan feces tikus tersebut. Keterbatasan lainnya adalah pencukuran bulu tikus yang kurang luas membuat dressing pada punggungnya tidak merekat dengan baik sehingga dengan aktivitas tikus yang sangat aktif dimalam hari dapat membuat dressing tersebut lepas sehingga dapat mempengaruhi kelembaban diperlukan konsentrasi dan hari yang bervariasi Dan juga luka yang di gunakan tidak hanya luka bakar saja tetapi dengan luka sayatan atau jenis luka lainnya.

Dari berbagai fakta yang ditemukan pada penelitian ini dan melalui kajian statistika,maka hipotesis tentang terdapatnya pengaruh pemberian gel ekstrak kulit kentang (Solanum Tuberosum L.) terhadap penurunan luas luka bakar derajat IIA pada tikus putih wistar terbukti. Pengaruh gel ekstrak kulit kentang (Solanum Tuberosum L.) adalah berupa penuruna luas luka bakar hal ini diduga kuat akibat efek antioksidan dan anti inflamasi yang terdapat di dalam gel ekstrak kulit kentang (Solanum Tuberosum L.).

\section{KESIMPULAN}

Pemberian gel ekstrak kulit kentang (Solanum Tuberosum L.) terbukti berpengaruh terhadap penurunan luas luka bakar derajat II(A) pada tikus putih strain wistar (Rattus norvegicus) dan semakin lama hari dalam pemberiannya akan dapat menurunkan luas luka semakin kuat.

\section{DAFTAR PUSTAKA}

Arif Usman,2013. Effect of wounding and light exposure on sterol, glycoalkaloid, and calystegine levels in potato plants (Solanum Tuberosum L. group Tuberosum). Jurnal of Swedish university of Agricultural Sciences Uppsala pp 14-16

Blauer Michael Jacob 2013."Factors Affecting Tubers Ascorbate Content,Physiological Age,Tuber Set And Size Distribution In Potato". Washington State University Program in Molecular Plant Sciences.

Diegelmann F.Robert, Melissa C.Evans,2004.”Wound bealing: An overview of acute,fibrotic, and delayed healing.Journal Frontiers in Biosciences9,283-289 


\section{VOLUME 12 NOMOR 1 JUNI 2016}

Erlia Eva,Noor Cahaya, Dina Rahmawaty,2014. Pengaruh Pemberian Gel Kuersetin Terhadap Jumlah Neutrofil dan Limfosit dalam Proses Penyembuhan Luka Bakar Derajat II A Pada Tikus Jantan Galur Wistar, Prodi Farmasuu FMIPA Universitas Lambung Mangkurat.

Fatemi Javad Mohammad, Nikoomaram B, Rahimi AA, Talayi D,Taghavi S, Ghavami Y,2014. "Effect of Green Tea on The Second Degree Burn Wounds in Rats.Indian Journal of Plastic Surgery : Official Publication of the Association of Plastic Surgeons of India.

Grunwald TB,Garner WL,2008.”'Acute Burns.Plast reconstr Surg;121:311e-9e

Hettiaratchy S,Papini R,2004. "Initial management of a major burn: II-assesment and resuscitation. BMJ.329:101-3

J a m e s, W. D., B e r ge r, T. G., \& E l s t o n D.M.2006." Andrews'diseases of the skin:Clinical dermatology(10 th). Philadelphia: Elsevier

Saunders Keast, D., et al.2009. The Basics Principles of Wound Healing.Health Manajement Publication. Vol. 3 